REVIEWS

\title{
Molecular Biomarkers: New Approaches in Ovarian Cancer Diagnosis
} \author{
Manzhura $^{5}$ \\ ${ }^{1}$ Institute of Molecular Biology and Genetics of NAS of Ukraine \\ 150, Acad. Zabolotny Str., Kyiv, 03143, Ukraine \\ ${ }^{2}$ P.L. Shupyk Medical Academy of Post-Graduate Education of Kyiv \\ 16, Geroiv Stalingrada Str., Kyiv, 04210, Ukraine \\ ${ }^{3}$ ISIDA Clinic \\ 65, Ivan Lepse Blvd, Kyiv, 03126, Ukraine \\ ${ }^{4}$ O.O. Bogomolets National Medical University of Kyiv \\ 13, Taras Shevchenko Blvd, Kyiv, 01004, Ukraine \\ ${ }^{5}$ Kyiv City Oncology Clinic \\ 7, Verkhovynna Str., Kyiv, 03115, Ukraine
}

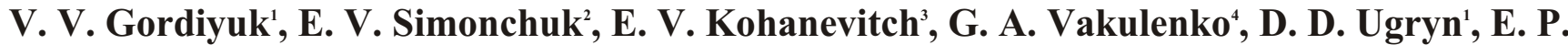

\begin{abstract}
Formation of tumors is associated with accumulation of different genetic and epigenetic changes. The current review summarizes the recent data on molecular markers of human ovarian cancer, as well as provides analysis of the contribution of epigenetic markers for early cancer diagnostics. Specificities of functioning of signaling pathways are considered in the context of searching for possible oncomarkers. The importance of complex evaluation of molecular changes for correct diagnostics and prognosis of ovarian cancer is demonstrated.
\end{abstract}

Keywords: ovarian tumor, early diagnostics of cancer, epigenetic markers, tumor suppressor, microarrays.

The review summarizes the data on potential molecular markers of ovarian tumors and makes effort to assess the possibilities of their application in medicine.

Tumor markers in clinics Tumor markers are both genes and their products, related to malignant tumors formation [1]. Cancer antigens (high-molecular weight glycoprotein CA125, detected using monoclonal antibodies, and CA72-4) are basic clinical markers in cases of ovarian cancer of different malignancy degrees $[2,3]$. It is noteworthy that the increase in CA125 concentration can be connected not only with

C V. V. GORDIYUK, E. V. SIMONCHUK, E. V. KOHANEVITCH, G. A. VAKULENKO, D. D. UGRYN, E. P. MANZHURA, 2006 malignization development, but also with formation of various benign tumors, chronic inflammatory processes, as well as normal physiological cycle of women, which influence the reliability of diagnostics [4].

Initial stages of ovarian tumor formation take place almost asymptomatically. In $70 \%$ of ovarian cancer patients, the tumors are diagnosed at metastasized condition [5]. Determining the set of molecular markers for ovarian tumors would allow conducting effective screening and therapy at early stages of cancer diagnostics, detecting micrometastases in the course of treatment, and performing monitoring during the stage of remission. 
Epigenetic markers in ovarian cancer diagnostics All cell processes are controlled by means of methylation [6]. As a rule, methylation of DNA is performed by $\mathrm{CpG}$-sites in non-coding sequences. Changes in methylation status were defined for variety of genes - ovarian cancer markers, and the progressing increase in hypomethylation due to increase of malignancy degree was demonstrated [7].

14-3-3y factor, participating in DNA reparation, shows methylation of all $17 \mathrm{CpG}$-islands in cases of ovarian carcinomas [8]. Increase in MBD2 expression (methyl-CpG binding domain protein) is correlated with its hypomethylation and progression in ovarian cancer [7, 9]. However, the inverse relation could be observed in tumorogenesis, for instance, it has been found in case of colorectal cancer [10].

Changes in methylation in the course of tumor formation may be predicted long before, sometimes a year before malignization detection by other methods. The use of NotI-microarrays enables performing simultaneous detection of deletions, amplifications, and also epigenetic methylation of genes [11], which would allow the definition of markers at early stages of tumor development.

Markers of early ovarian cancer diagnostics The following potential markers of benign and borderline ovarian tumors are to be indicated: G-CSF cytokine (granulocyte colony stimulating factor) [12]; OGP (oviduct glycoprotein), significant for gameto- and embryogenesis [13]; GLUT-4 (glucose transporter 4), regulator of glucose level [14], P-LAP (placental leucine aminopeptidase), responsible for amino acids exchange [14], Ki-67 antigen, which participates in rearrangements of chromatin during cell cycle interphase $[15,16]$; IGF 1 growth factor (insulin-like growth factor) [17]. Increase in expression of these genes results in changes in cell homeostasis and stimulation of growth. Decrease in expression level from benign to malignant tumors was shown for transcription factor BRCA1 (breast cancer 1, product of tumor suppressor gene) [18].

Borderline tumors are of special interest. Molecular markers for borderline tumors are adequate to those of early malignancy stages. Panel of antigens has been suggested as molecular oncomarkers for early ovarian cancer diagnostics [19]. According to Lu et al. [20], complex evaluation of markers (CLDN3 (claudin 3), MUC1 (mucin 1), VEGF (vascular endothelial growth factor), CA125) allowed diagnosing ovarian cancers with the probability higher than $99 \%$.

The increase in level of TADG-15 (tumor associated differentially expressed gene 15 protein) expression at the first stage of ovarian cancer, as well as its decrease during tumor progression, is typical of tumors [21]. Increase in telomerase activity, in particular, in serous carcinomas of ovaries, and the relation between hTERT (human telomerase reverse transcriptase) activation and high microsatellite instability were shown $[22,23]$. The difference in expression of ribosomal genes for borderline and malignant tumors [24], and hypermethylation of GC-rich clusters of ribosomal genes were detected [25]. High level of somatic mitochondrial mutations, e.g. for DNA region encoding $12 \mathrm{~S}$ and $16 \mathrm{~S}$ RNA, has been observed in cases of ovarian cancer [26]. Differences in Ras mutations in borderline and malignant tumors were shown. Many genes, considered to be potential markers of ovarian cancer, are expressed under the control of cytokines. At the same time, cytokines can be used for assessment of malignization in different combinations, including those together with CA125 $[12,27]$.

Change of methylation status was shown for BRCA1 in case of ovarian cancer: methylation frequency was shown to be higher in serous carcinomas than in mucinosal and endometrioid ones. Loss of heterozygosity $(\mathrm{LOH})$ for BRCA1 was not detected in benign tumors, weakly demonstrated in borderline tumors, and turned out to be specific for the majority of malignant ovarian tumors [18]. Increase in satellite DNA quantity in two chromosomal areas was demonstrated at early malignization stages [28, 29].

Cell signaling pathways at ovarian cancer Many potential ovarian tumor markers are known to be important members of cell signaling pathways. The key role in malignization is performed by PIK $3 \mathrm{~K}$ (phosphatidylinositol 3-kinase)/Akt-pathway [30]. Insulin and VEGF activate Akt-kinase; tumor suppressor PTEN (phosphatase and tensin homolog), either mutated or with decreased expression, causes the same effect. In current pathology activation of PI3K/Akt involves c-Src, cytoplasmic tyrosine kinase and Ras. Akt activation is often connected with high 
level of Akt expression or changes in PI3K, and rarely it is connected with the absence of functional PTEN. Other signaling pathways, depending on NFkB (nuclear factor $\mathrm{\kappa B}$ ), MAPK (mitogen-activated protein kinase), PKC (protein kinase C), cross-talk with $\mathrm{PI} 3 \mathrm{~K} /$ Akt-cascade at ovarian cancer.

Increased level of telomerase expression, the activity of which is correlated with clinical stage of the disease, is observed in more than $90 \%$ of malignant ovary tumors [31]. JNK-(c-jun-terminal kinase) signaling pathway is involved in regulation of telomerase activity at ovarian cancer. Oestrogen (ER) in endometrial and endometrioid cells may be activated by MEKK1, apparently, via p38/JNK signaling pathways [32]. ER may also be activated via K-Ras-dependent cascade by the way of ER Erk phosphorylation. Activation of K-Ras is often detected in ovarian carcinomas [33]. ER interacts with ovarian oncogene AIB1 (amplified in breast cancer 1), which results in acetylation of core histones and activation of expression of gene, involved in regulation of anti-apoptosis, immortalization, angiogenesis, and invasion. In case of BRCA1 binding with ER, deacetylation of histones blocks expression of the genes listed above.

The abovementioned increase in expression level of AIB1, Src, and Ras oncogenes, as well as IGF-1R (insulin-like growth factor 1 receptor) and EGFR (endothelial growth factor receptor), and inactivation of such tumor suppressor genes as BRCA1, PTEN, p53 in case of ovarian cancer results in activation of several signaling pathways, including PI3K/Akt/PTEN, MAPK/ERб, JNK/p38/hTERT, Wnt/B - catenin/Tcf [34], Jak/STAT3 [35], IGF-1/IGF-1R [30]. There are also other products of proto-oncogenes, participating in signaling pathways, listed as follows: JAK2 (janus kinase 2) [35], в-catenin [34], FGF20 (fibroblast growth factor) [36], as well as tumor suppressors (bikunin [37], BEXL1 (brain expressed X-linked-like 1) [38], ezrin [39], OPCML (opioid-binding protein/cell adhesion molecule-like gene) [40] with changed expression. There are also signaling molecules (hormones, transcription activators, mitogenic growth factors), which participate in activation of cascades and play an important role in ovarian cancer development.
Proteomic microarrays allow determining post-translational modifications, which are impossible to assess using genomic microarrays. The method of revealing the changes in the degree of phosphorylation of signaling proteins, derived from primary and disseminated tumors, was suggested in order to determine phenotypic variations with subsequent selection of specific kinase inhibitors as therapeutic means. It was revealed that in the majority of cases such difference is determined by expression of phosphorylated form of trans-membrane receptor tyrosine kinase c-kit, which is correlated with the last stages and resistance to chemotherapy in cases of serous ovarian carcinomas [41].

The correlation between histological tumors and changes at molecular level is of special interest. Individual signaling pathways components, specific changes for which were discovered in definite types/stages of ovarian cancer, were previously suggested to be used as markers. For cases of clear cell ovarian cancer, NHF-1в was used as marker [42]. In serous and endometrial carcinomas, mutations (dysfunctions) of BRCA1 and BRCA2, as well as higher level of $\mathrm{B} 7-\mathrm{H} 4$ expression compared to the mucinous ones, were indicated. At early stages of serous carcinomas, RAS-RAF (MAPK)-signaling pathway is activated to a greater extent due to mutations in KRAS and BRAF. In mucinous carcinomas, mutation of KRAS [44] and increased expression of GAL4 (galectin 4) compared to benign and borderline tumors [45] have been revealed.

Conclusions The use of different methods often leads to principally dissimilar selections of genes, whose expression level changes in current pathology. Control for oncomarkers specificity presumes comparison of corresponding samples to the norm and benign tumors samples, as well as to those for diseases not connected with malignization. The presupposed marker cannot always be revealed in physiological fluids of the patient. Unfortunately, insufficient specificity of single markers, applied in medicine, allows diagnosing only some tumors.

Ovarian cancer integrates the group of neoplasms, which are characterized by high aggressiveness, which makes it more difficult to treat, and such treatment requires complex approach [46]. In oncotherapy the 
emphasis from point targets is shifted to non-toxic agents of wide spectrum, i.e. tyrosine kinase inhibitors, angiogenesis inhibitors, cytokine balance regulators [47]. A number of genes-markers of ovarian malignant tumors are the objects for therapy elaboration, e.g. HNF1в (hepatocyte nuclear factor beta), and HER2 $[48,49]$.

In future the use of single clinical factors as markers will be replaced by systematic approaches, including multiple factors, e.g. molecular and genetic markers. Improved and standardized microarray technology (NotI-microarrays are the most perspective at the moment) will allow defining various combinations of prognostic factors, and may be used in diagnostics by screening and comparison of genetic and epigenetic changes and expression on the level of genes and proteins.

В. В. Гордиюк, Е. В. Симончук, Е. В. Коханевич, Г. А. Вакуленко, Д. Д. Угрин, Е. П. Манжура

Молекулярные биомаркеры: новые подходы в диагностике опухолей яичников

Резюме

Прочесс возникновения опухолей связан с накоплением различных генетических и эпигенетических изменений. В обзоре суммированы данные по молекулярным маркерам опухолей яичников, полученные благодаря развитию современных технологий, и проанализирована роль эпигенетических маркеров в ранней диагностике рака. Особенности функичионирования сигнальных путей рассматриваются в контексте поиска вероятных онкомаркеров. Отмечено значение комплексной оценки молекулярных изменений для корректного диагноза и прогнозирования развития рака яичников.

Ключевые слова: опухоли яичников, ранняя диагностика рака, эпигенетические маркеры, супрессоры опухолей, NotI-микрочипы.

\section{REFERENCES:}

1.Лактионов К. К., Давыдов М. И, Полоцкий Б. Е Прогностические и предсказывающие факторы у больных немелкоклеточным раком легкого // Практическая онкология.- 2006.- 7, № 3.- С. 145-153.

2. Crombach G., Zippel H. H., Wurz H. Experiences with CA 125, a tumor marker for malignant epithelial ovarian tumors // Geburtshilfe Frauenheilkd. - 1985.- 45.- P. 205-212.

3. Panidis D., Vlassis G., Matalliotakis J., Skiadopoulos S., Kalogeropoulos A. Serum levels of the oncofetal antigens CA-125, CA 19-9 and CA 15-3 in patients with endometriosis // J Endocrinol Invest. $-1988 .-11 .-$ P. 801-804.

4. Гриневич Ю. А., Югринова Л. Г.,. Свинцицкий В. С. Роль СА 125 в диагностике и мониторинге рака яичников // Журнал сучасного лікаря. Мистецтво лікування.- 2005. -17, № 5. - С. 83-86.

5. Трофимова М. Н., Никитин А.Ю Рак яичников: морфогенез, патогенез, экспериментальное воспроизведение // Вопросы онкологии. - 2004. - 50. № 4. - С. 387-398.
6. Vanyushin B.F. Enzymatic DNA Methylation is an Epigenetic Control for Genetic Functions of the Cell // Biochemiistry (Mosc). 2005. - 70. - P. 488-499.

7. Hattori M., Sakamoto H., Yamamoto T. DNA demethylase expression correlates with lung resistance protein expression in common epithelial ovarian cancers // J Int Med Res. - 2001. -29. - P. 204-213.

8. Mhawech P., Benz A., Cerato C., Greloz V., Assaly M., Desmond J. C., Koeffler H. P., Lodygin D., Hermeking H., Herrmann F., Schwaller J. Downregulation of 14-3-3sigma in ovary, prostate and endometrial carcinomas is associated with $\mathrm{CpG}$ island methylation // Mod Pathol. - 2005. -18. - P. 340-348.

9. Hattory M., Sakamoto H., Satoh K., Yamamoto T. DNA demethylase is expressed in ovarian cancers and the expression correlates with demethylation of $\mathrm{CpG}$ sites in the promoter region of c-erb-2 and survivin genes // Cancer Lett. - 2001. - 169. - P. 155-164.

10. Kanai Y., Ushijima S., Nakanishi Y., Hirobashi S. 1999. Reduced mRNA expression of the DNA demethylase, MBD2, in human colorectal and stomach cancers // Biochem. Biophs. Res. Commun. 1999. -264. - P. 962-966.

11. Braga E. A., Kisselev L. L., Zabarovsky E. R. From identification of genomic polymorphisms to diagnosticand prognostic markers of human epithelial tumors // Mol. Biol. - 2004.- 38.- P. 179-190.

12. van't Veer L. J., Dai H., van de Vijver M. J. Gene expression profiling predicts clinical outcome of breast cancer// Nature.- 1999.-415.-P. 530-536.

13. Woo M. M., Gilks C. B., Verhage H. G., Longacre T. A., Leung P. C., Auersperg N. Oviductal glycoprotein, a new differentiation-based indicator present in early ovarian epithelial neoplasia and cortical inclusion cysts // Gynecol Oncol. - 2004. - 93. - P. 315-319.

14. Shibata K., Kajiyama H., Mizokami Y., Ino K., Nomura S., Mizutani S., Terauchi M., Kikkawa F. Placental leucine aminopeptidase (P-LAP) and glucose transporter 4 (GLUT4) expression in benign, borderline, and malignant ovarian epithelia // Gynecol Oncol. - 2005. -98. - P. 11-18.

15. Darai E., Walker-Combrouze F., Dauge-Geoffroy M. C., Vincent Y., Feldmann G., Madelenat P., Scoazec J. Y. Ki 67 expression in 35 borderline ovarian tumours: relations with clinicopathologic parameters and ploidy // Eur J Obstet Gynecol Reprod Biol. - 1998. 76. - P. $175-180$

16. Kuhn W., Marx D., Meidel A., Fattahi-Meibodi A., Korabiowska M., Ruschenburg I., Droese M., Schauer A., Meden H. Borderline tumors of the ovary: a clinico-pathologic and immunohistochemical study of 54 cases // J Obstet Gynaecol Res. - 1998. - 24. - P. 437-445.

17. Warrenfeltz S., Pavlik S., Datta S., Kraemer E. T., Benigno B., McDonald I. F. Gene expression profiling of epithelial ovarian tumors correlated with malignant potential // Mol Cancer. - 2004. - 7. - P. 3-27.

18. Wang C., Horiuchi A., Imai T., Ohira S., Itoh K., Nikaido T., Katsuyama Y., Konishi I. Expression of BRCA1 protein in benign, borderline, and malignant epithelial ovarian neoplasms and its relationship to methylation and allelic loss of the BRCA1 gene // J. Pathol. - 2004. - 202. - P. 215-223.

19. Chatterjee M., Mohapatra S., Ionan A. Diagnostic markers of ovarian cancer by high throughput antigen cloning and detection on arrays // Cancer Res. - 2006. -15. - P. 1181-1190.

20. Lu K. H., Patterson A. P., Wang L., Marquez R. T., Atkinson E. N., Baggerly K. A., Ramoth L. R., Rosen D. G, Liu J., Hellstrom I., Smith D., Hartmann L., Fishman D., Berchuck A., Schmandt R., Whitaker R., Gershenson D. M, Mills G. B, Bast R. C. Selection of potential markers for epithelial ovarian cancer with gene expression arrays and recursive descent partition analysis // Clin Cancer Res. - 2004 . - 10. P. 3291-3300

21. Tanimoto H., Shigemasa K., Tian X., Gu L., Beard J. B., Sawasaki T., O'Brien T. J. Transmembrane serine protease TADG-15 (ST14/Matriptase/MT-SP1): expression and prognostic value in ovarian cancer // Br J Cancer. - 2005. -92. - P. 278-283. 
22. Brustmann H. Immunohistohemical detection of human telomerase reverse transcriptase (hTERT) and c-kit in serous ovarian carcinoma: a clinicopathologic study // Ginecol Oncol. -2005. - 98. - P. 396-402.

23. Landen C. N., Klingelhutz A., Koffin J. E., Sorosky J. I., Sood A. K. Genomic instability is associated with lack of telomeraseactivation in ovarian cancer // Cancer Biol Ther. - 2004. -3. - P. 1250-1253.

24. Welsh J. B., Zarrinkar P. P., Sapinoso L. M., Kern S. G. Analisis of gene expression profiles in normal and neoplastic ovarian tissue samples identifies candidate molecular markers of epithelial ovarian cancer // Proc Natl Acad Sci USA. - 2001. -98. - P. 1176-1181.

25. Chan M. W., Wei S. H., Wen P., Wang Z. Hypermethylation of $18 \mathrm{~S}$ and 28S ribosomal DNAs predicts progression-free survival in patients with ovarian cancer // Clin Cancer Res. - 2005. -11. - P. 7376-7383.

26. Liu V. W. High incidence of somatic mitochondrial DNA mutations in human ovarian carcinomas // Cancer Res. - 2001. - 61. - P. 5998-6001.

27. Kusuda T., Shigemasa K., Arihiro K., Fujii T., Nagai N., Ohama K. Relative expression levels of Th1 and Th2 cytokine mRNA are independent prognostic factors in patients with ovarian cance //. Oncol Rep. - 2005. -13. - P. 1153-1158.

28. Widschwendter M., Jiang G., Woods C., Muller H. M., Fiegl H., Goebel G., Marth C., Muller-Holzner E., Zeimet A. G., Laird P. W. Ehrlich M. DNA hypomethylation and ovarian cancer biology // Cancer Res. - 2004. -64. - P. 4472-4480.

29. Dellas A., Puhl A., Schraml P., Thomke S. E., Ruschoff J., Mihatsch M. J., Moch H. Molecular and clinicopathological analysis of ovarian carcinomas with and without microsatellite instability //Anticancer Res-2004. -24. - P. 361-369.

30. Nicosia S. V., Bai W., Cheng J. Q., Coppola D., Kruk P. A. Oncogenic pathways implicated in ovarian epithelial cancer // Hematol Oncol Clin North Am. - 2003. -17. - P. 927-943.

31. Kyo S., Kanaya T., Ishikawa H., Ueno H., Inoue M. Telomerase activity in gynecological tumors // Clin Cancer Res. - 1996. -2. - P. 2023-2028.

32. Lee H., Jiang F., Wang Q., Nicosia S. V., Yang J., Su B. MEKK1 activation of human estrogen receptor alpha and stimulation of the agonistic activity of 4-hydroxytamoxifen in endometrial and ovarian cancer cells // Mol Endocrino. - 2000. -14. - P. 1882-1896.

33. Kato S., Endoh H., Masuhiro Y., Kitamoto T., Uchiyama S., Sasaki H. Activation of the estrogen receptor through phosphorylation by mitogen-activated protein kinase // Science. 1995. - 270. - P. 1491-1494.

34. Marques F. R., Fonsechi-Carvasan G. A., De Angelo Andrade L. A., Bottcher-Luiz F., Immunohistochemical patterns for alpha- and beta-catenin, E- and $\mathrm{N}$-cadherin expression in ovarian epithelial tumors // Gynecol Oncol. - 2004. - 94. - P. 16-24.

35. Reid T., Jin X., Song H., Tang H. J., Reynolds R. K., Lin J. Modulation of Janus kinase 2 by p53 in ovarian cancer cells // Biochem Biophys Res Commun. - 2004. -321. - P. 441-447.

36. Chamorro M. N., Schwartz D. R., Vonica A., Brivanlou A. H., Cho K. R., Varmus H. E. FGF-20 and DKK1 are transcriptional targets of beta-catenin and FGF-20 is implicated in cancer and development //EMBO J. - 2005. - 24. - P. 73-84

37. Matsuzaki H., Kobayashi H., Yagyu T., Wakahara K., Kondo T., Kurita N., Sekino H., Inagaki K., Suzuki M., Kanayama N., Terao T. Plasma bikunin as a favorable prognostic factor in ovarian cancer// J Clin Oncol. - 2005. -23. - P. 1463-1472.
38. Chien J., Staub J., Avula R., Zhang H., Liu W., Hartmann L. C., Kaufmann S. H., Smith D. I., Shridhar V. Epigenetic silencing of TCEAL7 (Bex4) in ovarian cancer // Oncogene. - 2005. -24. - P 5089-5100.

39. Song J., Fadiel A., Edusa V., Chen Z., So J., Sakamoto H., Fishman D. A., Naftolin F. Estradiol-induced ezrin overexpression in ovarian cancer: a new signaling domain for estrogen // Cancer Lett. - 2005. 20. - P. 57-65.

40. Mei F. C., Young T. W., Liu J., Cheng X. RAS-mediated epigenetic inactivation of OPCML in oncogenic transformation of human ovarian surface epithelial cells. - FASEB J. - 2006. -20 . - P. 497-499.

41. Sheehan K. M., Calvert V. S., Kay E. W. Use of Reverse Phase Protein Microarrays and Reference Standard Development for Molecular Network Analysis of Metastatic Ovarian Carcinoma // Mol. and Cell. Proteomics. - 2005. - 4. - P. 346-355.

42. Kato N., Sasou S., Motoyama T. Expression of hepatocyte nuclear factor-1beta (HNF-1beta) in clear cell tumors and endometriosis of the ovary // Mod Pathol. $-2006 .-19 .-$ P. 83-89.

43. Simon I., Zhuo S., Corral L., Diamandis E. P., Sarno M. J., Wolfert R. L., Kim N. W. B7-h4 is a novel membrane-bound protein and a candidate serum and tissue biomarker for ovarian cancer // Cancer Res. - 2006. -66. - P. 1570-1575.

44. Bell D. A. Origins and molecular pathology of ovarian cancer // Mod Pathol. - 2005. -18. - P.S19-32.

45. Heinzelmann-Schwarz V.A., Gardiner-Garden M., Henshall S.M., Scurry J.P., Scolyer R.A., Smith A.N., Bali A., Vanden Bergh P., Baron-Hay S., Scott C., Fink D., Hacker N.F., Sutherland R.L., O'Brien P.M. A distinct molecular profile associated with mucinous epithelial ovarian cancer // Br J Cancer. - 2006. - 94. - P. 904-913.

46. Bapat S. A., Mali A. M., Koppikar C. B., Kurrey N. K. Stem and progenitor-like cells contribute to the aggressive behavior of human epithelial ovarian cancer // Cancer Res. - 2005. -65. - P. 3025-3029.

47. Mencher S. K., Wang L. G. Promiscuous drugs compared to selective drugs // BMC Clin Pharmacol. - 2005. - 5. -P. 3.

48. Takai N., Jain A., Kawamata N., Popoviciu L. M., Said J. W., Whittaker S., Miyakawa I., Agus D. B., Koeffler H. P. 2C4, a monoclonal antibody against HER2, disrupts the HER kinase signaling pathway and inhibits ovarian carcinoma cell growth // Cancer. - 2005. -104. - P.2701-2708.

49. Tsuchiya A., Sakamoto M., Yasuda J., Chuma M., Ohta T., Ohki M., Yasugi T., Taketani Y., Hirohashi S. Expression profiling in ovarian clear cell carcinoma: identification of hepatocyte nuclear factor-1 beta as a molecular marker and a possible molecular target for therapy of ovarian clear cell carcinoma // Am J Pathol. - 2003. - 163. - P. 2503-2512. 